\title{
On the importance of long-term functional assessment after stroke to improve translation from bench to bedside
}

\author{
Thomas Freret*, Pascale Schumann-Bard, Michel Boulouard and Valentine Bouet
}

\begin{abstract}
Despite extensive research efforts in the field of cerebral ischemia, numerous disappointments came from the translational step. Even if experimental studies showed a large number of promising drugs, most of them failed to be efficient in clinical trials. Based on these reports, factors that play a significant role in causing outcome differences between animal experiments and clinical trials have been identified; and latest works in the field have tried to discard them in order to improve the scope of the results. Nevertheless, efforts must be maintained, especially for long-term functional evaluations. As observed in clinical practice, animals display a large degree of spontaneous recovery after stroke. The neurological impairment, assessed by basic items, typically disappears during the firsts week following stroke in rodents. On the contrary, more demanding sensorimotor and cognitive tasks underline other deficits, which are usually long-lasting. Unfortunately, studies addressing such behavioral impairments are less abundant. Because the characterization of long-term functional recovery is critical for evaluating the efficacy of potential therapeutic agents in experimental strokes, behavioral tests that proved sensitive enough to detect long-term deficits are reported here. And since the ultimate goal of any stroke therapy is the restoration of normal function, an objective appraisal of the behavioral deficits should be done.
\end{abstract}

\section{Letter to the editor}

Regarding functional evaluations, the first point to consider is the body weight. Monitoring body weight changes after a stroke is of prime importance since postoperative weight loss may indicate feeding difficulties. Aside from all ethical considerations, such postoperative weight loss has been shown by some authors to be correlated with the extent of the lesion (extensive corticostriatal damage [1], or the involvement of the external carotid artery territory in the lesion [2]). An easy measurement such as this can advise as to the severity of the lesion. Beyond the lesion per se, feeding difficulties may also result from a reduced consciousness level or poor mobility due to anesthesia and/or surgery. For example, a surgical approach in which the temporal muscle is injured, such as the Tamura model [3] may induce severe mastication impairments, resulting thus in higher body weight loss. Nevertheless, a poor nutritional

\footnotetext{
* Correspondence: thomas.freret@unicaen.fr

GMPc - Groupe Mémoire et Plasticité comportementale, EA4259, Université de Caen Basse-Normandie, Caen, France
}

intake (Dennis, 2000) can be a bias, since it has been shown in patients [2] as in animals to have a negative effect on functional outcomes after stroke [2]. Body weight monitoring of patients has even been recommended as an index of functional outcome [4]. Thus, investigating weight changes in preclinical studies has to be recommended for all authors in the field, since it gives an independent and unambiguous assessment of animal welfare and safety. Animals should be weighed at least once before surgery and then regularly after. This parameter, accessible to everyone and not only to behaviorists since it does not require any specific skill, can also give, in some ways, information on how animals recover from surgery and can even be a prognostic index for functional outcome.

Concerning functional evaluations, few studies consider crucial long-term evaluation, even though it has been highly recommended during the Stroke Therapy Academic Industry Roundtables [5-7]. As in clinical practice [8], animals display a large degree of spontaneous recovery within a short time after experimental cerebral ischemia [9-12]. Even though demanding 
Table 1 Available and helpful sensorimotor tests assessing longitudinal and long-term functional recovery

\begin{tabular}{|c|c|c|c|c|c|}
\hline & $\begin{array}{l}\text { Behavioral } \\
\text { test }\end{array}$ & Brief description & $\begin{array}{l}\text { Time } \\
\text { points }\end{array}$ & Advantages & Concerns \\
\hline \multirow[t]{8}{*}{$\begin{array}{l}\text { SENSORI- } \\
\text { MOTOR } \\
\text { FUNCTIONS }\end{array}$} & $\begin{array}{l}\text { Neurological } \\
\text { scales }\end{array}$ & $\begin{array}{l}\text { Neurological score for } 4 \text { to } 6 \text { items } \\
\text { (ranking from normal motor function: } \\
\text { spontaneous walk initiation, circling } \\
\text { behavior; to normal posture at rest: limb } \\
\text { slipping arms, head tilting, hand crossing } \\
\text { the chest; or when lifted by the tail for } \\
\text { rodents only: flexion of torso and } \\
\text { controlateral forelimb, decreased of } \\
\text { controlateral forelimb grip). }\end{array}$ & $\begin{array}{l}\text { Few } \\
\text { days to } \\
\text { a week } \\
\text { [33] }\end{array}$ & $\begin{array}{l}\text { * Inter-species } \\
\text { comparisons: non- } \\
\text { human primate and } \\
\text { rodents (mouse, rat, } \\
\text { gerbil) } \\
\text { * Useful to access the } \\
\text { acute phase of } \\
\text { cerebral ischemia }\end{array}$ & $\begin{array}{l}\text { * Requires animal contention } \\
\text { * Highly variable from a lab to another } \\
\text { according to the number of evaluation } \\
\text { criteria included and to the procedure } \\
\text { which is highly experimenter-dependant }\end{array}$ \\
\hline & $\begin{array}{c}\text { Limb placing } \\
\text { test }\end{array}$ & $\begin{array}{c}\text { Sensorimotor and proprioceptive } \\
\text { abilities: sensorimotor responses of } \\
\text { fore- and hindlimbs to tactile, visual, and } \\
\text { proprioceptive stimuli. }\end{array}$ & $\begin{array}{l}\text { Till } 2-3 \\
\text { weeks } \\
\text { [34] }\end{array}$ & & \\
\hline & Cylinder test & $\begin{array}{c}\text { Limb-use asymmetry: preference for } \\
\text { using the non-impaired forelimb for } \\
\text { weight shifting movement. Animal is } \\
\text { placed in a cylinder and limb use } \\
\text { asymmetry is observed during rearing } \\
\text { with support. }\end{array}$ & $\begin{array}{l}\text { Few } \\
\text { weeks } \\
{[35,36]}\end{array}$ & $\begin{array}{l}* \text { Easy to perform } \\
* \text { No need of animal } \\
\text { contention }\end{array}$ & $\begin{array}{l}\text { * Cannot be done in the acute phase, } \\
\text { since it needs a certain level of recovery }\end{array}$ \\
\hline & $\begin{array}{l}\text { Grip strength } \\
\text { test }\end{array}$ & $\begin{array}{c}\text { Muscular strength: forelimb muscular } \\
\text { strength with a Newton meter attached } \\
\text { to a triangular steel wire grasped by the } \\
\text { animal. }\end{array}$ & $\begin{array}{l}\text { Few } \\
\text { weeks to } \\
\text { a month } \\
{[37]}\end{array}$ & $\begin{array}{l}\text { * Quantitatively } \\
\text { measured by a } \\
\text { Newton meter }\end{array}$ & * Specific apparatus required \\
\hline & $\begin{array}{c}\text { Beam walking } \\
\text { test }\end{array}$ & $\begin{array}{l}\text { Locomotor function: evaluation of } \\
\text { forelimb and hindlimb faults while } \\
\text { traversing along a ledged tapered beam. }\end{array}$ & $\begin{array}{c}\text { Few } \\
\text { weeks } \\
{[38,39]}\end{array}$ & $\begin{array}{l}\text { * Easy to perform } \\
\text { * No need of } \\
\text { expensive materials }\end{array}$ & $\begin{array}{l}\text { * Cannot be done until postural bias } \\
\text { and circling behaviors have not } \\
\text { disappeared }\end{array}$ \\
\hline & $\begin{array}{l}\text { Rotarod test } \\
\text { (constant or } \\
\text { accelerated) }\end{array}$ & $\begin{array}{c}\text { Balance and motor coordination: } \\
\text { measure of latency to fall off a rotating } \\
\text { rod (speed of rotation can be constant } \\
\text { or increasing) }\end{array}$ & $\begin{array}{l}\text { weeks } \\
{[40,41]}\end{array}$ & $\begin{array}{l}\text { * Easy to perform } \\
{ }^{*} \text { Quantitative } \\
\text { measures }\end{array}$ & $\begin{array}{l}* \text { * Cost of apparatus } \\
\text { * May require a training session }\end{array}$ \\
\hline & $\begin{array}{l}\text { Adhesive } \\
\text { removal test }\end{array}$ & $\begin{array}{l}\text { Somatosensory and motor function: } \\
\text { measure of the requested time to sense } \\
\text { and to remove the adhesives placed on } \\
\text { the animal's body (forelimb, hindlimb or } \\
\text { snout). } \\
\text { Of note, performance at this task has } \\
\text { been shown to be strictly independent } \\
\text { of postural bias and circling behaviors }\end{array}$ & $\begin{array}{l}\text { From } \\
\text { weeks } \\
{[22] \text { to }} \\
\text { months } \\
{[42,43]}\end{array}$ & $\begin{array}{l}\text { * Inter-species } \\
\text { comparisons: non- } \\
\text { human primate and } \\
\text { rodents (mouse, rat, } \\
\text { gerbil) }\end{array}$ & $\begin{array}{l}\text { * May require a training session } \\
\text { * Requires animal contention }\end{array}$ \\
\hline & $\begin{array}{l}\text { Reach to } \\
\text { grasp test/ } \\
\text { Skilled } \\
\text { reaching test/ } \\
\text { staircase test }\end{array}$ & $\begin{array}{c}\text { Forelimb ability and dexterity: } \\
\text { measure of the ability to reach food } \\
\text { pellets }\end{array}$ & $\begin{array}{c}\text { From } \\
\text { weeks } \\
{[44,45]} \\
\text { to } \\
\text { months } \\
{[43]}\end{array}$ & $\begin{array}{l}\text { * Inter-species } \\
\text { comparisons: non- } \\
\text { human primate and } \\
\text { rodents (mice, rat) } \\
\text { * independent } \\
\text { forelimb reaching } \\
\text { ability }\end{array}$ & $\begin{array}{l}\text { * Requires a food restriction } \\
\quad * \text { Time-consuming } \\
\text { * May require a training session }\end{array}$ \\
\hline \multirow[t]{3}{*}{$\begin{array}{l}\text { MNESIC } \\
\text { FUNCTIONS }\end{array}$} & $\begin{array}{l}\text { Morris water } \\
\text { maze }\end{array}$ & $\begin{array}{l}\text { Spatial memory task: Measure of the } \\
\text { required distance and time, to get to a } \\
\text { escape platform, hidden under the } \\
\text { surface of the water in a circular pool } \\
\text { tank }\end{array}$ & $\begin{array}{c}\text { weeks } \\
{[46]}\end{array}$ & $\begin{array}{l}{ }^{*} \text { Highly develop } \\
\text { since } 80 \text { 's, numerous } \\
\text { protocols existing } \\
\text { that can fit all request }\end{array}$ & $\begin{array}{l}\text { * Require a training session for the } \\
\text { learning phase and a retention phase } \\
\text { * Require a dedicated room to lodge } \\
\text { the pool } \\
\text { * Require a software for the tracking of } \\
\text { the animal }\end{array}$ \\
\hline & $\begin{array}{l}\text { Passive } \\
\text { avoidance }\end{array}$ & $\begin{array}{l}\text { Fear-motivated task: animal learns to } \\
\text { refrain from stepping through a door to } \\
\text { an apparently safer but previously } \\
\text { punished dark compartment }\end{array}$ & $\begin{array}{c}\text { From } \\
\text { days[47] } \\
\text { to weeks } \\
{[46]}\end{array}$ & $\begin{array}{l}\text { * One-trial task with } \\
\text { no need to learn a } \\
\text { rule }\end{array}$ & $\begin{array}{l}\text { * Require electrical foot shock that may } \\
\text { interfere with other behavioral test }\end{array}$ \\
\hline & $\begin{array}{l}\text { Object } \\
\text { recognition } \\
\text { test }\end{array}$ & $\begin{array}{l}\text { Non-spatial memory task: Measure of } \\
\text { spontaneous tendency of rodents to } \\
\text { spend more time exploring a novel } \\
\text { object than a familiar one. }\end{array}$ & $\begin{array}{l}\text { weeks } \\
{[48]}\end{array}$ & $\begin{array}{l}\text { * One-trial task with } \\
\text { no need to learn a } \\
\text { rule }\end{array}$ & \\
\hline
\end{tabular}


Table 1 Available and helpful sensorimotor tests assessing longitudinal and long-term functional recovery (Continued)

\begin{tabular}{|c|c|c|c|c|c|}
\hline \multirow[t]{2}{*}{$\begin{array}{c}\text { EMOTIONAL- } \\
\text { TRAIT }\end{array}$} & $\begin{array}{c}\text { Elevated plus } \\
\text { maze }\end{array}$ & $\begin{array}{c}\text { Anxiety-related behaviour: measure of } \\
\text { the time spent in anxiogenous (open) vs } \\
\text { safe (close) arms of a labyrinth }\end{array}$ & $\begin{array}{l}\text { Few } \\
\text { months } \\
{[27]}\end{array}$ & $\begin{array}{l}\text { * Easy to perform } \\
\text { * Inter-species } \\
\text { comparison (mouse, } \\
\text { rat) }\end{array}$ & $\begin{array}{l}\text { * Cannot be done until postural bias } \\
\text { and circling behaviors have not } \\
\text { disappeared }\end{array}$ \\
\hline & $\begin{array}{c}\text { Black \& white } \\
\text { box }\end{array}$ & $\begin{array}{c}\text { Anxiety-related behaviour: measure of } \\
\text { the preference to stay in a dark vs } \\
\text { illuminated compartment of a double- } \\
\text { box }\end{array}$ & & & \\
\hline
\end{tabular}

Time points when behavioral tests can discern sham-operated from stroked animals are given as an indication for a typical 30-50\% lesion size.

sensorimotor and cognitive tasks are powerful in revealing tiny deficits, long-term studies addressing such behaviors are unfortunately not very abundant. The characterization of long-term functional recovery is critical for evaluating the efficacy of potential therapeutic agents in an experimental stroke. Both acute (few days) and long-term (several weeks or months) evaluations have to be addressed in order to demonstrate a stable neuroprotection, and not only a slowing down of the lesion evolution $[13,14]$. The issue of including behavioral assessments in animal stroke studies becomes even more critical with the recent interest in neurorestorative strategies, which requires a longer period of administration than classical treatments. Effectiveness of such strategies is more likely observable via changes in synapse number and dendritic structure, for example, than by changes in infarct volume $[15,16]$. Since the ultimate goal of any stroke therapy is the restoration of functions that allow for a normal daily life of patients; an objective appraisal of the behavioral deficits should be done. Stroke-induced functional impairments can be divided into acute (pointing out effects of drugs on the rate of recovery - days or weeks) and long-term (pointing out the effects of drugs on the extent of recovery several weeks to months). Ideally, a set of several different tests has to be performed to gather complementary information (see table 1: behavioral tests and timepoints are given as an indication, and need to be adjusted according to the species/strain and the stroke model used). Several behavioral tests have been applied to ischemia research in regards to clinical criteria, from the simplest which measures global neurological status or motor reflexes (i.e. neurological score [17], limb placing test [18], cylinder test [19] - useful to assess an acute phase after stroke) to more complex tests assessing sensory and motor functions (i.e. adhesive removal [20] and rotarod or staircase [19,21-25]) - that are more relevant for the long-term phase. Similarly, cognitive tests such as those assessing memory functions are preferentially used for later time points because they require normalized motor functions [19,22,26-28]. These behavioral tests have to be carefully chosen in accordance with the drugs tested and the nature of the targeted cerebral structures. Except from that of Winter and colleagues [27], very few publications deal with stoke-induced disturbances in emotional behavior. Because anatomical and functional brain regions are affected on a different timescale, and because treatments may also differentially affect those regions, it is our view and that of others [29] that direct (cortex, striatum) or indirect (thalamus) anatomical substrates hit during stroke, rather than global brain lesions, may be critical determinants of behavioral impairments and outcome.

Whereas the correlation between acute histological lesions and early behavioral impairment is well documented[24], less is known about the long-term evolution of this relationship. Correlation studies have to take into account the different brain structures, primarily or secondarily affected by stroke, in order to bring a better understanding of their involvement in behavioral impairments [23,25,30]. Additionally, the development of non-invasive methods (such as MRI) allowing longitudinal assessment of the evolution of the lesion may bring new insights to understanding the mechanisms underlying spontaneous functional recovery [31]. Longitudinal correlations must then be promoted since therapeutic agents targeting those mechanisms will free us from the current mandatory 3 to 6 hour therapeutic window.

The use of clinically relevant models taking into account associated factors and/or pathologies (i.e. aging [32], arterial hypertension, diabetes, ..) have, moreover, to be reinforced in the incoming studies. As such, the post-ischemic recovery may be different, depending on the presence of these aggravating factors.

\section{Conflict of interests}

The authors declare that they have no competing interests.

\section{Acknowledgements}

Authors want to thank Kate Stanton for the English editing.

Received: 22 February 2011 Accepted: 18 June 2011

Published: 18 June 2011

\section{References}

1. Virtanen T, Jolkkonen J, Sivenius J: Re: External carotid artery territory ischemia impairs outcome in the endovascular filament model of 
middle cerebral artery occlusion in rats. Stroke 2004, 35:e9-10, author reply e9-10.

2. Dittmar M, Spruss T, Schuierer G, Horn M: External carotid artery territory ischemia impairs outcome in the endovascular filament model of middle cerebral artery occlusion in rats. Stroke 2003, 34:2252-7.

3. Tamura A, Graham DI, McCulloch J, Teasdale GM: Focal cerebral ischaemia in the rat: 1. Description of technique and early neuropathological consequences following middle cerebral artery occlusion. J Cereb Blood Flow Metab 1981, 1:53-60.

4. Jonsson AC, Lindgren I, Norrving B, Lindgren A: Weight loss after stroke: a population-based study from the Lund Stroke Register. Stroke 2008, 918-23.

5. Wahlgren NG, Ahmed N: Neuroprotection in cerebral ischaemia: facts and fancies-the need for new approaches. Cerebrovasc Dis 2004, 17(Suppl 1):153-66.

6. Green AR: Why do neuroprotective drugs that are so promising in animals fail in the clinic? An industry perspective. Clin Exp Pharmacol Physiol 2002, 29:1030-4

7. Fisher M, Hanley DF, Howard G, Jauch EC, Warach S: Recommendations from the STAIR V meeting on acute stroke trials, technology and outcomes. Stroke 2007, 38:245-8.

8. Rothrock JF, Clark WM, Lyden PD: Spontaneous early improvement following ischemic stroke. Stroke 1995, 26:1358-60.

9. Hunter AJ, Mackay KB, Rogers DC: To what extent have functional studies of ischaemia in animals been useful in the assessment of potential neuroprotective agents? Trends Pharmacol Sci 1998, 19:59-66.

10. Roof RL, Schielke GP, Ren X, Hall ED: A comparison of long-term functional outcome after 2 middle cerebral artery occlusion models in rats. Stroke 2001, 32:2648-57.

11. Zausinger S, Hungerhuber E, Baethmann A, Reulen H, Schmid-Elsaesser R: Neurological impairment in rats after transient middle cerebral artery occlusion: a comparative study under various treatment paradigms. Brain Res 2000, 863:94-105.

12. Zhang L, Chen J, Li Y, Zhang ZG, Chopp M: Quantitative measurement of motor and somatosensory impairments after mild ( $30 \mathrm{~min})$ and severe $(2 \mathrm{~h})$ transient middle cerebral artery occlusion in rats. J Neurol Sci 2000 174:141-6.

13. Valtysson J, Hillered L, Andine P, Hagberg H, Persson L: Neuropathological endpoints in experimental stroke pharmacotherapy: the importance of both early and late evaluation. Acta Neurochir (Wien) 1994, 129:58-63.

14. Corbett $D$, Nurse $S$ : The problem of assessing effective neuroprotection in experimental cerebral ischemia. Prog Neurobiol 1998, 54:531-48.

15. Biernaskie J, Corbett D: Enriched rehabilitative training promotes improved forelimb motor function and enhanced dendritic growth after focal ischemic injury. J Neurosci 2001, 21:5272-80.

16. Kawamata T, Alexis NE, Dietrich WD, Finklestein SP: Intracisternal basic fibroblast growth factor (bFGF) enhances behavioral recovery following focal cerebral infarction in the rat. J Cereb Blood Flow Metab 1996, 16:542-7.

17. Bederson JB, Pitts LH, Tsuji M, Nishimura MC, Davis RL, Bartkowski H: Rat middle cerebral artery occlusion: evaluation of the model and development of a neurologic examination. Stroke 1986, 17:472-6.

18. De Ryck M, Van Reempts J, Borgers M, Wauquier A, Janssen PA: Photochemical stroke model: flunarizine prevents sensorimotor deficits after neocortical infarcts in rats. Stroke 1989, 20:1383-90.

19. Bouet V, Freret T, Toutain J, Divoux D, Boulouard M, Schumann-Bard P: Sensorimotor and cognitive deficits after transient middle cerebral artery occlusion in the mouse. Exp Neurol 2007, 203:555-67.

20. Bouet V, Boulouard M, Toutain J, Divoux D, Bernaudin M, Schumann-Bard P, Freret T: The adhesive removal test: a sensitive method to assess sensorimotor deficits in mice. Nat Protoc 2009, 4:1560-4

21. Modo M, Stroemer RP, Tang E, Veizovic T, Sowniski P, Hodges H: Neurological sequelae and long-term behavioural assessment of rats with transient middle cerebral artery occlusion. J Neurosci Methods 2000, 104:99-109.

22. Freret $T$, Bouet V, Leconte $C$, Roussel $S$, Chazalviel L, Divoux D, SchumannBard P, Boulouard M: Behavioral deficits after distal focal cerebral ischemia in mice: Usefulness of adhesive removal test. Behav Neurosci 2009, 123:224-30.

23. Freret $T$, Chazalviel L, Roussel $S$, Bernaudin $M$, Schumann-Bard $P$, Boulouard M: Long-term functional outcome following transient middle cerebral artery occlusion in the rat: correlation between brain damage and behavioral impairment. Behav Neurosci 2006, 120:1285-98.

24. Rogers DC, Campbell CA, Stretton JL, Mackay KB: Correlation between motor impairment and infarct volume after permanent and transient middle cerebral artery occlusion in the rat. Stroke 1997, 28:2060-5, discussion 2066.

25. Grabowski M, Brundin P, Johansson BB: Paw-reaching, sensorimotor, and rotational behavior after brain infarction in rats. Stroke 1993, 24:889-95.

26. Borlongan CV, Cahill DW, Sanberg PR: Locomotor and passive avoidance deficits following occlusion of the middle cerebral artery. Physiol Behav 1995, 58:909-17.

27. Winter B, Juckel G, Viktorov I, Katchanov J, Gietz A, Sohr R, Balkaya M, Hortnagl H, Endres M: Anxious and hyperactive phenotype following brief ischemic episodes in mice. Biol Psychiatry 2005, 57:1166-75.

28. DeVries AC, Nelson RJ, Traystman RJ, Hurn PD: Cognitive and behavioral assessment in experimental stroke research: will it prove useful? Neurosci Biobehav Rev 2001, 25:325-42

29. Virley D, Beech JS, Smart SC, Williams SC, Hodges H, Hunter AJ: A temporal MRI assessment of neuropathology after transient middle cerebral artery occlusion in the rat: correlations with behavior. I Cereb Blood Flow Metab 2000, 20:563-82.

30. Hudzik TJ, Borrelli A, Bialobok P, Widzowski D, Sydserff S, Howell A, Gendron P, Corbett D, Miller J, Palmer GC: Long-term functional end points following middle cerebral artery occlusion in the rat. Pharmacol Biochem Behav 2000, 65:553-62.

31. van Meer MP, van der Marel K, Wang K, Otte WM, El Bouazati S, Roeling TA, Viergever MA, Berkelbach van der Sprenkel JW, Dijkhuizen RM: Recovery of sensorimotor function after experimental stroke correlates with restoration of resting-state interhemispheric functional connectivity. J Neurosci 2010, 30:3964-72.

32. Moore TL, Killiany RJ, Pessina MA, Moss MB, Finklestein SP, Rosene DL: Recovery from ischemia in the middle-aged brain: a nonhuman primate model. Neurobiol Aging 2011

33. Encarnacion A, Horie N, Keren-Gill H, Bliss TM, Steinberg GK, Shamloo M: Long-term behavioral assessment of function in an experimental model for ischemic stroke. J Neurosci Methods 2011, 196:247-57.

34. Dijkhuizen RM, Ren J, Mandeville JB, Wu O, Ozdag FM, Moskowitz MA Rosen BR, Finklestein SP: Functional magnetic resonance imaging of reorganization in rat brain after stroke. Proc Natl Acad Sci USA 2001, 98:12766-71

35. Rogalewski A, Dittgen T, Klugmann M, Kirsch F, Kruger C, Pitzer C, Minnerup J, Schabitz WR, Schneider A: Semaphorin 6A improves functional recovery in conjunction with motor training after cerebral ischemia. PLoS One 2010, 5:e10737.

36. Hicks AU, Hewlett K, Windle V, Chernenko G, Ploughman M, Jolkkonen J, Weiss $S$, Corbett D: Enriched environment enhances transplanted subventricular zone stem cell migration and functional recovery after stroke. Neuroscience 2007, 146:31-40.

37. Reitmeir R, Kilic E, Kilic U, Bacigaluppi M, ElAli A, Salani G, Pluchino S, Gassmann M, Hermann DM: Post-acute delivery of erythropoietin induces stroke recovery by promoting perilesional tissue remodelling and contralesional pyramidal tract plasticity. Brain 2011, 134:84-99.

38. Brown AW, Bjelke B, Fuxe K: Motor response to amphetamine treatment, task-specific training, and limited motor experience in a postacute animal stroke model. Exp Neurol 2004, 190:102-8.

39. Hatinen S, Sairanen M, Sirvio J, Jolkkonen J: Improved sensorimotor function by rolipram following focal cerebral ischemia in rats. Restor Neurol Neurosci 2008, 26:493-9.

40. Jin K, Wang X, Xie L, Mao XO, Greenberg DA: Transgenic ablation of doublecortin-expressing cells suppresses adult neurogenesis and worsens stroke outcome in mice. Proc Natl Acad Sci USA 2010, 107:7993-8.

41. Ferrara A, El Bejaoui S, Seyen S, Tirelli E, Plumier JC: The usefulness of operant conditioning procedures to assess long-lasting deficits following transient focal ischemia in mice. Behav Brain Res 2009, 205:525-34.

42. Leconte C, Tixier E, Freret T, Toutain J, Saulnier R, Boulouard M, Roussel S, Schumann-Bard P, Bernaudin M: Delayed Hypoxic Postconditioning Protects Against Cerebral Ischemia in the Mouse. Stroke 2009.

43. Freret T, Valable S, Chazalviel L, Saulnier R, Mackenzie ET, Petit E, Bernaudin M, Boulouard M, Schumann-Bard P: Delayed administration of deferoxamine reduces brain damage and promotes functional recovery 
after transient focal cerebral ischemia in the rat. Eur J Neurosci 2006, 23:1757-65.

44. Baird AL, Meldrum A, Dunnett SB: The staircase test of skilled reaching in mice. Brain Res Bull 2001, 54:243-50.

45. Tennant KA, Jones TA: Sensorimotor behavioral effects of endothelin-1 induced small cortical infarcts in C57BL/6 mice. J Neurosci Methods 2009, 181:18-26.

46. Haelewyn B, Freret T, Pacary E, Schumann-Bard P, Boulouard M, Bernaudin $\mathrm{M}$, Bouet $\mathrm{V}$ : Long-term evaluation of sensorimotor and mnesic behaviour following striatal NMDA-induced unilateral excitotoxic lesion in the mouse. Behav Brain Res 2007, 178:235-43.

47. Wahl F, Allix M, Plotkine M, Boulu RG: Neurological and behavioral outcomes of focal cerebral ischemia in rats. Stroke 1992, 23:267-72.

48. Esneault E, Castagne V, Moser P, Bonny C, Bernaudin M: D-JNKi, a peptide inhibitor of c-Jun $\mathrm{N}$-terminal kinase, promotes functional recovery after transient focal cerebral ischemia in rats. Neuroscience 2008, 152:308-20.

doi:10.1186/2040-7378-3-6

Cite this article as: Freret et al: On the importance of long-term

functional assessment after stroke to improve translation from bench to bedside. Experimental \& Translational Stroke Medicine 2011 3:6.

\section{Submit your next manuscript to BioMed Central} and take full advantage of:

- Convenient online submission

- Thorough peer review

- No space constraints or color figure charges

- Immediate publication on acceptance

- Inclusion in PubMed, CAS, Scopus and Google Scholar

- Research which is freely available for redistribution

Submit your manuscript at www.biomedcentral.com/submit 